\title{
VI. MISCELLANEOUS.
}

Democratic Ideals and Reality. By H. J. Mackinder, M. P. A Study in the Politics of Reconstruction. Henry Holt \& Co. 266 pp. $\$ 2.00$ net.

The author is one of the world's leading geographers and he uses his knowledge with fine effect. He has keen insight into the causes of the great war and shows how impossible a lasting peace will be if the lawis of geography and of trade are not observed. The key to Asia is the Balkans. To rule Asia in his opinion is to rule the world. The book is full of force and is timely. A. T. ROBERTSON.

Mary Oliver: A Life. By May Sinclair. The Macmillan Company, New York. \$2.00.

A desperately sad book, with a piercing but bitter psychology. Mary's story suggests George Eliot's experience. The loneliness of her struggle is overpowering, and she never finds any but blind guides. The early chapters are the best and contain some significant studies of a child's lovely instincts, secret broodings and misconceptions of religion and life. ELLA B. ROBERTSON.

David Darrin's South American Cruise. By H. Irving Hancock. Volumes 3, 4, 5. The Dave Darrin Series. Henry Altemus, Philadelphia. 75 cts. a copy.

These books belong to one of Mr. Hancock's well known series of boy stories. He has a bill-of-fare of some fifty or more, and they seem to go and interest the boys.

Deep Waters. By W. W. Jacobs, Author of "Night Watches", "The Castaways", etc. Charles Scribners' Sons, New York, 1919. 290 p. Irlustrated. $\$ 1.60$.

These tories of sailor life are fresh as the salt sea breeze and as bracing. They are good for the tired man or woman who wishes relaxation and genuine forgetfulness of care and toil. There is deliclous humor that is clean and hearty. Mr. Jacobs holds one's attention by his knowledge of human nature and by his manifest love for men, even the humblest men. The book is wholesome and helpful to the spirit.

ELLA B. ROBERTSON. 